\title{
DIE BEROEPSORIËNTASIE VAN PROFESSIONEEL-REKENINGKUNDIGES TYDENS DIE VROEË BEROEPSJARE
}

\author{
L.J. VAN VUUREN \\ M.M. FOUCHÉ \\ Departement Bedryfsielkunde \\ Randse Afrikaanse Universiteit
}

A.M. VERWEY

SA Philips

Johannesburg

\begin{abstract}
The career orientation of professional accountants during the early career stage. The purpose with this study was to conduct research into the career orientations of aspiring and qualified persons in the accounting profession. Schein's Career Orientation Inventory was administered to 221 respondents in the early career stage and in different phases of involvement in the profession. Managerial skill featured as the most prominent career orientation. It was also evident that respondents who had had occupational experience measured highest on the same orientation, i.e. managerial skill, irrespective of their phase within the early career stage. Furthermore, there were indications that career orientation differentiation increased in accordance with occupational experience.
\end{abstract}

\section{OPSOMMING}

Die doel met hierdie studie was om die beroepsoriēntasies van aspirant en gekwalifiseerde persone in die rekenmeesterprofessie na te vors. Schein se Beroepsoriëntasievraelys is afgeneem op 221 proefpersone in hul vroeẻ beroepsjare en in verskillende fases van betrokkenheid in die professie. Bestuursbedrewenheid is as die mees kenmerkende beroepsoriëntasie geìdentifiseer. Dit het ook aan die lig gekom dat proefpersone wat oor beroepsondervinding beskik. ongeag hul fase van betrokkenheid in die vroeë beroepsjare, dieselfde oriēntasie naamlik bestuursbedrewenheid. realiseer. Aanduidings is verder verkry dat beroepsoriēntasie-differensiasie na gelang van beroepsblootstelling toeneem.

Die huidige tekort aan hoëvlakmannekrag in Suid-Afrika bring mee dat syfers vir die trefwydte van beheer per toesighouer/bestuurder nie aan aanbevelings en vereistes in hierdie verband voldoen nie. Hierdie verskynsel gee daartoe aanleiding dat bestuursposte uit die geledere van professionele beroepsgroepe gevul moet word. Situasies ontstaan egter gereeld in die praktyk waar professionele persone uit hul spesialiteitsareas na bestuursposisies bevorder word, ongeag hul spesifieke beroepsoriëntasies. Hierteenoor word persone soms bevorder na poste wat bestuursfunksies binne hul spesialiteitsarea behels. maar sonder dat hul persepsie en vaardighede betreffende bestuur in ag geneem word. Hierdie situasies kan moontlike onsekerhede vir die professionele persone impliseer en dus ook doeltreffende funksionering van hul organisasies inhibeer. ' $n$ Beroepsgroep wat veral deur hierdie verskynsel gekenmerk word, is die rekenmeesterprofessie.

\section{Die rekenmeesterprofessie}

Die eiesoortige probleme wat die rekenmeesterprofessie kenmerk is reeds deur verskeie navorsers aangespreek (Aranya en Ferris, 1984; Aslanian en Duff, 1973; Carey, 1968; De Coster en Rhode, 1972; De Villiers, 1979; Goetz, 1967; Jacoby, 1980). Hieruit blyk dit dat die rekeningkunde tradisioneel en hedendaags as 'n konserwatiewe professie beskou word wat dikwels verwar word met "vervelige, geroetineerde boekhouding". Ander geïdentifiseerde probleemareas is die organisatories-

Versoeke vir afdrukke moet gerig word aan L.J. van Vuuren, Departement Bedryfsielkunde, Randse Afrikaanse Universiteit, Posbus 524, Johannesburg, 2000. professionele konflik wat rekenmeesters ervaar; die oriëntasie van rekeningkundige akademici wat te ver van die praktyk verwyderd is; die bewering dat sommige akademici nie die vereiste professionele standaard by hul studente kweek nie; en 'n oormaat taak- eerder as mensoriëntasie wat geopenbaar word.

Die heersende stereotipe beeld van rekenmeesters - wat 'n minder aanvaarbare inslag impliseer - is deur die volgende literatuurbevindinge versterk. Maslow beweer dat rekenmeesters oor beperkte verbale bedrewenheid beskik, verkies om met syfers te werk, hoogs gedetailleerd te werk gaan en 'n gebrek aan kreatiwiteit toon (Aranya, Meir en Bar-Ilan, 1978). Volgens Aranya et al. (1978) het O'Dowd en Beardslee bevind dat rekenmeesters gekenmerk word deur konformiteit, 'n lae vlak van sosiale belangstelling en 'n swak ontwikkelde estetiese sensitiwiteit. Gray (1963) toon dat rekenmeesters 'n rigiditeit van standpunt en 'n weerstand teen verandering openbaar en dat sosiale belonings nie vir hulle 'n primêre motiveringsfaktor is nie. 'n Vergelykende studie deur Aranya et al. (1978) het aangetoon dat aspirantrekenmeesters neig om in 'n groter mate te voldoen aan sosiale norme en waardes as wat dit die geval is met sielkunde studente. 'n Aantal skrywers wys ook daarop dat bevind is dat rekeningkundige persone eerder beoordelend en taakgerig is, en dit moeilik vind om met mense te werk (Jacoby, 1980; Segal en Szabo, 1964; Thielens in De Coster en Rhode, 1972).

Navorsingsresultate wat oënskynlik 'n ander perspektief voorhou, is die van De Coster en Rhode (1972). Hulle het naamlik aangetoon dat rekenmeesters hoër tellings ten opsigte van 
vriendelikheid, selfaanvaarding en sosialisering as ander professionele groepe realiseer. Jacoby (1980) noem ook dat rekenmeesters as 'n groep oor die algemeen meer innovasie en minder weerstand teen verandering as die algemene bevolking openbaar. Aranya, Barak en Amernic (1981) het op grond van die persoonlikheidstipologie voorgestel deur Holland (1973) aangetoon dat professionele rekenmeesters ten beste beskryf kan word deur 'n kombinasie van die volgende persoonlikheidstipes: konvensioneel, ondernemend en sosiaal.

\section{Die vroeë beroepsjare}

Afgesien van die groot aantal teorieë oor die lewensiklus, is daar etlike teorieë wat spesifiek gerig is op die mens se beroepsiklus. So blyk dit duidelik uit teorieë van byvoorbeeld Campbell en Heffernan (1983), Hall en Nougaim (1968), Miller en Form (1964), Schein (1978) en Super (1968) dat die beroepsiklus uit vier of vyf fases bestaan wat 'n aanvang neem by beroepskeuse en eindig met die tydperk voor aftrede. Die fase binne die beroepsiklus wat pertinent betrekking het op hierdie studie is dié van die vroeë beroepsjare. Indien aanvaar word dat opleiding deurgaans 'n onderliggende komponent van die vroeë beroepsjare is, en dat die vroeë beroepsjare duur vanaf beroepstoetrede tot die middel-beroepsjare, kan hierdie tydperk in drie subfases verdeel word. Die subfases is naamlik die ondersoekende fase, die vestigingsfase en die oorgangsfase na die middelberoepsjare.

Kenmerke van die ondersoekende fase is dat dit die een is waartydens 'n persoon in 'n gereedheidstoestand is om 'n sogenaamde blanko gedeelte van sy lewensruimte in te klee (Van Maanen, 1977); ' $n$ toenemende sosialiseringstaak van die individu vereis word (Bingham, 1983); blootstelling aan etlike beroepsuitdagings voorkom (Gould, 1979): frustrasie ervaar word tydens die poging om self sinvolle uitdagings te skep (Hall, 1976): en 'n inkongruensie tussen die individu se behoeftes en vaardighede en die eise wat sy werkgewende organisasie stel, aan die orde van die dag is.

Tydens die vestigingsfase aanvaar die individu die realiteite van 'n organisasie, hy hanteer weerstand teen verandering en leierselemente, en hy ontwikkel 'n identiteit binne die organisasie (Schein, 1978). Sover dit die beroepslewe betref leer die individu om effektief binne sy groep te funksioneer (Campbell en Heffernan, 1983), hy verskerp toenemend sy vaardighede en leef hom uit binne sy beroepsrol (Healy, 1982), rolle word vir hom meer afgebaken en bekend (Stumph en Rabinowitz, 1981), en sy beroepsbetrokkenheid is intens (Rabinowitz en Hall, 1981).

Die oorgangsfase na die middel-beroepsjare is die een waartydens 'n persoon sy unieke beroepslewe as die een met die beste geleenthede vir bevrediging en beloning in die toekoms aanvaar (Isaacson, 1985; Levinson, Darrow, Klein, Levinson en McKee, 1978). Die persoon strewe ook nou na volle beroepslidmaatskap indien hy dit nie reeds ervaar het nie (Schein, 1978). Dit is in hierdie fase waar die persoon sy beroepsanker begin oorweeg, sy doelwitte in heroorweging neem en langtermynplanne beraam of bevestig.

Gedagtig aan die beroepsgroep onder beskouing in hierdie studie, naamlik professionele rekeningkundiges, is dit nodig om melding te mak van die teorie van die professionele beroepsiklus van Dalton. Thompson en Price (1982). Op grond van Dalton et al. (1982) se navorsing met 550 professionele persone in vier beroepsgroepe (rekenmeesters, wetenskaplikes, ingenieurs en akademici) blyk dit dat die vroeë beroepsjare van 'n professionele persoon gekenmerk word deur die vertolking van die rol van ' $n$ vakleerling, ' $n$ intensiewe leerproses en af- hanklikheid. So 'n persoon se posisie verander stelselmatig na een waar hy ' $n$ onafhanklike bydraer en kollega word, in teenstelling met sy vroeëre rol van vakleerling.

Indien aangeneem word dat heelwat jong professionele persone, waaronder jong rekeningkundiges noodwendig ressorteer, redelik gou bestuursposte in organisasies bereik, ervaar hierdie persone by implikasie heelwat probleme as jong bestuurders. Sulke probleme kan binne die konteks van Dalton et al. (1982) se professionele beroepsiklus beskou word en is reeds deur verskeie navorsers in oënskou geneem (Bray, Campbell en Grant, 1979; Graves, 1982; Hall, 1982; en Webber, 1982).

Tricker (1967) huldig die siening dat professionele rekenmeesters soos hulle in hul beroep vorder, hulself in die een of ander stadium op 'n kontinuum bevind. Hierdie kontinuum verteenwoordig die oriëntasie van die rekenmeester betreffende sy behoefte aan ' $n$ bestuursrol. Op die een uiterste is daar die rekenmeester wat homself uitsluitlik wil bepaal by die rekeningkundige aspekte van die professie, terwyl daar op die teenoorgestelde pool van die kontinuum die persoon is wat wil bestuur eerder as om gemoeid te wees met rekeningkundige tegnieke. Tussen hierdie twee uiterstes word die persoon aangetref wat 'n funksionele bestuursoriëntasie het. So 'n persoon gee dus nie om om as ' $n$ bestuurder te funksioneer nie, mits dit steeds in die veld van die rekeningkunde is. Dit blyk dat die meting van 'n persoon se beroepsoriëntasie of beroepsankerpatroon wat juis in die middelberoepsfase hoogs gedifferensieerd behoort te wees, moontlik ' $n$ aanduiding kan verskaf van waar op die kontinuum die persoon moet funksioneer ten einde sy ontplooide beroepselfkonsep uit te leef.

\section{Die ontwikkeling van 'n beroepsoriëntasie}

Soos reeds genoem begin 'n persoon in die oorgangsfase na die middelberoepsjare sy beroepsanker oorweeg. Volgens Schein (1978) doen 'n persoon, namate hy in sy beroepslewe vorder, meer selfkennis op (meesal vanweë terugvoer uit sy omgewing) en verkry hy stelselmatig meer duidelikheid aangaande ' $n$ sogenaamde "beroepselfkonsep". Die beroepselfkonsep bestaan uit drie komponente, wat in kombinasie die persoon se beroepsanker vorm (Schein, 1978):

1. Selfwaargenome talente en vermoëns (gebaseer op werklike sukses behaal in 'n verskeidenheid werksituasies);

2. Selfwaargenome motiewe en behoeftes (gebaseer op geleenthede vir selfdiagnose en -evaluering in werklike situasies wat gegrond word op terugvoering van andere);

3. Selfwaargenome houdings en waardes (gebaseer op werklike konfrontasies tussen die self en die norme en waardes van die organisasie en werkopset).

Schein (1978) meld dat die beroepsanker "binne 'n persoon is en dat die anker 'n kombinasie of patroon is van die selfwaargenome talente, motiewe en waardes, en dat dit 'serves to guide, constrain, stabilize, and integrate the person's career' " (p.127). Dit blyk uit die literatuur dat werklike werkervaring 'n voorvereiste is vir die ontwikkeling van 'n anker (Derr, 1980), en dat die realisering van ' $n$ anker 'n persoon se toekomstige beroepsbesluite beïnvloed ongeag die akkuraatheid van enige van die genoemde selfwaarnemings (DeLong, 1982). Kenmerkend van ' $n$ anker is voorts dat dit fokus op daardie aspekte ten opsigte waarvan die individu 'n gevoel van bedrewenheid ervaar (DeLong, 1982), dat dit by implikasie stabiel bly deur 'n persoon se hele loopbaan (Derr, 1980), en dat dit daardie element in 'n persoon se selfkonsep is wat nooit prysgegee word nie, al ontstaan moeilike keuse-situasies (Schein, 1982). 
Uit die werk van Derr (1980) is dit duidelik dat 'n beroepsanker oor tyd ontplooi. Dié ontplooiing neem 'n aanvang enkele jare na beroepstoetrede. Dit is ook opmerklik dat die ontplooiing 'n proses is waardeur 'n ankerpatroon stelselmatig meer gedifferensieerd voorkom en tydens die laat-middelberoepsjare as 'n stabiele patroon kulmineer. Daar is gevolglik geen sprake van 'n "aha!"'-gevoel en 'n momentele realisering van 'n anker nie.

Die vyf primêre ankers is in 1975 deur Schein (1975) bekend gestel en is die volgende: 1) bestuursbedrewenheid, 2) tegniesfunksionele vaardigheid, 3) sekuriteit, 4) kreatiwiteit, en 5) outonomie en onafhanklikheid. Navorsing het sedertdien getoon dat identiteit (organisatories of beroep), dienslewering, verskeidenheid, lewenstyl, mag en uitdaging ook elkeen 'n selfstandige anker is of variante van die primêre ankers is (Schein, 1978, 1982). (Die tipes ankers, die onderskeidende kenmerke daarvan en die tipiese poste en beroepe wat met elke ankertipe geassosieer kan word, word breedvoerig verduidelik in Schein $(1978 ; 1982 b))$.

Betreffende die professioneel-rekeningkundige se moontlike beroepsankers het Schein (1982b) deur middel van empiriese navorsing met finansiële bestuurders gevind dat die tegnies/funksionele anker vir twee proefgroepe gerealiseer het. Benewens hierdie studie is weinig navorsingsresultate wat die beroepsankers van professioneel-rekeningkundiges ondersoek, gegenereer.

\section{Die meting van beroepsoriëntasie}

Aangesien beroepsankers nie sondermeer met behulp van 'n meetinstrument voorspel kan word nie, moet daar gevolglik tydens navorsing met persone in hul vroeë beroepsjare staatgemaak word op die persepsie van die proefpersone betreffende hul beroepsankerontplooiing. Hierdie persepsie word gevorm op grond van vroeë beroepservaringe, -mislukkinge, en -suksesse. 'n Nuttige hulpmiddel wat gevolglik 'n aanduiding van 'n moontlike beroepsanker by sulke proefpersone kan verskaf, is die Career Orientation Inventory van Schein en DeLong. Hierdie meetinstrument bepaal beroepsoriëntasie en tesame met 'n gestruktureerde onderhoud 'n proefpersoon se beroepsanker. Volgens DeLong (1982) is die begrip beroepsoriëntasie 'n kernkomponent van die definisie van die beroepsankerkonsep. Op grond hiervan is ' $n$ persoon se beroepsanker ' $n$ samestelling van sy beroepsoriëntasie (behoeftes, houdings en waardes) en sy selfwaargenome talente. Met behulp van die voorgestelde gestruktureerde onderhoud (Schein, 1982a), kan ' $n$ individu se selfwaargenome talente vasgestel word. Deur die Career Orientation Inventory aan te wend, word 'n persoon se selfwaargenome behoeftes, houdings en waardes (sy beroepsoriëntasie dus), gemeet en 'n goeie aanduiding van sy moontlike beroepsanker word gevolglik verskaf.

Soos vroeër genoem is daar geen navorsingsresultate van die beroepsankers en/of die oriëntasies van professioneelrekeningkundige persone per se beskikbaar nie. Die formulering van verwagte resultate het gevolglik noodwendig berus op insigte verkry uit die bestudering van relevante beroepsankerteorie. Na aanleiding hiervan is verwag dat die rekening. kundige proefgroep in geheel die tegnies/funksionele anker sou realiseer. Persone met so 'n oriëntasie se selfbeeld is gekoppel aan hul vermoë om in 'n spesifieke spesialisasie-rigting te funksioneer, en hulle word gemotiveer deur 'n bewustheid van hul vaardighede in 'n spesifieke werk. Daar is ook verwag dat die beroepsidentiteitoriëntasie na vore sou kom, veral gesien in die lig van die feit dat ' $n$ spesifieke beroep vir rekeningkundiges 'n sentrale beroepstema behoort te wees, en dat daar tradisioneel aansienlike status en prestige aan dié beroep gekoppel is.

Teen die voorgaande agtergrondskets was die doel met hierdie studie om inligting te bekom aangaande die beroepsoriëntasie(s) van professioneel-rekeningkundige persone wat hulself in die stadium van die vroeë beroepsjare bevind. Voortvloeiend uit die probleem van konfliksituasies wat onstaan wanneer professioneel-rekeningkundige persone in 'n vroeë stadium van hul beroepslewe na bestuursposte moet beweeg, kan daar moontlik aanwendbare inligting via die vasstelling van die beroepsoriëntasie(s) van sulke persone genereer word. Die empiriese komponent van hierdie studie wat hierna bespreek word, is na aanleiding van die volgende hipoteses deurgevoer:

\section{Hipotese 1}

Professioneel-rekeningkundige persone beskik oor verskillende beroepsoriëntasies tydens verskillende stadia van hul beroepsjare.

\section{Hipotese 2}

Die mate waarin die beroepsoriëntasies van professioneel. rekeningkundige persone gedifferensieer is, verskil vir persone in verskillende stadia van die vroeë beroepsjare.

\section{METODE}

\section{Steekproef}

Vir die doel van die navorsing is vier groepe respondente in hul vroeë beroepsjare wat regstreeks met die rekenmeesterprofessie gemoeid is, dit wil sê praktiserend en/of in opleiding, ewekansig geïdentifiseer. Die samestelling van die steekproef word in Tabel 1 verduidelik:

TABEL 1

SAMESTELLING VAN DIE STEEKPROEF

\begin{tabular}{lcccc}
\hline Groep & $\begin{array}{c}\text { Grootte } \\
\text { van } \\
\text { Groep }\end{array}$ & Mans & $\begin{array}{c}\text { Dames } \\
\text { Gemiddelde } \\
\text { ouderdom }\end{array}$ \\
\hline 1. Eerstejaar B.Com. (Rek.)-studente (voltyds) & 51 & 35 & 16 & 18,75 \\
2. B.Com. (Rek.) (Honneurs)-studente (deeltyds) & 65 & 54 & 11 & 23,86 \\
3. *GR's in ouditeursfirmas & 56 & 51 & 5 & 26,23 \\
4. GR's in privaat- of openbare sektor & 50 & 44 & 6 & 29,15 \\
\hline \multicolumn{1}{c}{ Totaal } & 222 & 184 & 38 & 24,46 \\
\hline *GR = Geoktrooieerde Rekenmeester & & & &
\end{tabular}

*GR = Geoktrooieerde Rekenmeester 


\section{Meetinstrument}

Die meetinstrument wat in hierdie ondersoek gebruik is, is die selfdiagnostiese Beroepsoriëntasievraelys (Career Orientation Inventory) van Schein en De Long (Schein, 1982a). Die vraelys bestaan uit 41 items, en elke item vereis 'n respons op 'n sespunt-Likertskaal. Response op die 41 items verskaf 'n telling vir elk van nege skale wat elk die sterkte van 'n respondent se beroepsoriëntasie aandui. Die nege skale is soos volg benoem:

1. Tegnies/funksioneel

2. Bestuursbedrewenheid

3. Outonomie/onafhanklikheid

4. Sekuriteit 1: gebaseer op dienstydperk

5. Sekuriteit 2: gebaseer op geografiese stabiliteit

6. Dienslewering/toegewydheid tot 'n goeie saak

7. Organisatoriese-/beroepsidentiteit

8. Verskeidenheid

9. Entrepreneurskap/kreatiwiteit

Die vraelys en items is op so 'n wyse gekonstrueer dat daar vir elke respondent nege gemiddelde skaaltellings verkry word wat aan hom nege beroepsoriëntasies van wisselende intensi- teite toeken. Die hoogste skaaltelling verteenwoordig ' $n$ respondent se gemete beroepsoriëntasie en verskaf gevolglik 'n aanduiding van sy beroepsanker. Dit moet in gedagte gehou word dat die vraelys selfdiagnosties van aard is en alleenlik in samehang met ' $n$ gestruktureerde onderhoud 'n meting van 'n persoon se beroepsanker kan verskaf. Dit moet genoem word dat aan die eerstejaarsgroep (Groep 1) instruksies gegee is dat hulle hul persepsie van hul moontlike toekomstige beroepsoriëntasies op die antwoordblad moes weergee, aangesien ankers/oriëntasies slegs op grond van werkondervinding realiseer.

\section{RESULTATE EN BESPREKING}

\section{Beroepsoriëntasies van die steekproef}

Die gemete beroepsoriëntasies word vir die onderskeie groepe van die steekproef in Tabel 2 aangedui. Aangesien daar verwag is dat Groepe 3 en 4 dieselfde resultate behoort te realiseer, is daar in Tabel 2 'n afsonderlike kolom vir hul gesommeerde resultate bygevoeg. Die resultate van die steekproef as geheel word ook verskaf. Dit dien gemeld te word dat vir die doeleindes van die huidige bespreking slegs die mees prominente beroepsoriëntasies soos afgelei uit Tabel 2 breedvoerig bespreek sal word.

TABEL 2

\section{GEMETE BEROEPSORIËNTASIES}

\begin{tabular}{|c|c|c|c|c|c|c|c|c|c|c|c|c|}
\hline \multirow[b]{2}{*}{ Oriëntasie } & \multicolumn{2}{|c|}{1} & \multicolumn{2}{|c|}{2} & \multicolumn{2}{|c|}{3} & \multicolumn{2}{|c|}{4} & \multicolumn{2}{|c|}{$3+4$} & \multicolumn{2}{|c|}{$1+2+3+4$} \\
\hline & $\overline{\mathbf{x}}$ & $\mathbf{s}$ & $\overline{\mathbf{x}}$ & $\mathbf{s}$ & $\overline{\mathbf{x}}$ & $\mathbf{s}$ & $\overline{\mathbf{x}}$ & $\mathbf{s}$ & $\overline{\mathbf{x}}$ & $\mathbf{S}$ & $\hat{\mathbf{x}}$ & $\mathbf{s}$ \\
\hline 1. Tegnies/Funksioneel & 3,7922 & 0,5628 & 3,7231 & 0,7935 & 3,3036 & 1,0184 & 3,0930 & 1,0970 & 3,2057 & 1,0559 & 3,4932 & 0.9263 \\
\hline 2. Bestuursbedrewenheid & 353 & 0,6749 & 4,8246 & 0,6119 & 5,0143 & 0,6670 & 4,9592 & 0,6868 & 4,9886 & 0,6736 & 4,8588 & 0,6685 \\
\hline 3. Outonomie/Onafhanklikheid & 4,2039 & 0,8462 & 4,4308 & 0,9194 & 4,3893 & 0,9220 & 4,4571 & 0,8524 & 4,4210 & 0,8866 & 4,3738 & 0,8882 \\
\hline 4. Sekuriteit: Dienstydperk & 4,8562 & 1,0028 & 4,2051 & 1,1191 & 3,7083 & 1,1531 & 3.5986 & 1,1607 & 3.6571 & 1,1523 & 4,0950 & 1,2042 \\
\hline 5. Sekuriteit: Geografies & 3,7908 & 1,2110 & 3,3744 & 1,2590 & 3,2083 & 1,5250 & 3,5034 & 1,4690 & 3,3460 & 1,4992 & 3,4570 & 1,3750 \\
\hline 6. Dienslewering & 4,4235 & 0,8968 & 4,1908 & 0,6941 & 4,0429 & 0,8142 & 4,0939 & 0,8298 & 4,0667 & 0,8179 & 4,1855 & 0,8118 \\
\hline \multirow{3}{*}{$\begin{array}{l}\text { 7. Organisasie-/Beroeps- } \\
\text { identiteit } \\
\text { 8. Verskeidenheid } \\
\text { 9. Entrepreneurskap/Kreati- } \\
\text { witeit }\end{array}$} & 1002 & 0,9264 & 3,6677 & 1,2431 & 3,7179 & 1,1642 & 3,4980 & 1,1159 & 3,6152 & 1,1418 & 3,7629 & 1,1471 \\
\hline & 4,6980 & 0,6202 & 4,7200 & 0,6926 & 4,6679 & 0,7791 & 5,0531 & 0,6516 & 4,8476 & 0,7445 & 4,7756 & 0,7027 \\
\hline & 4,7020 & 0,6734 & 4,7231 & 0,8787 & 4,4429 & 0,7009 & 4,6286 & 0,7047 & 4,5295 & 0,7055 & 4,6262 & 0,7562 \\
\hline $\mathrm{N}=$ & \multicolumn{2}{|c|}{51} & \multicolumn{2}{|c|}{65} & \multicolumn{2}{|c|}{56} & \multicolumn{2}{|c|}{ 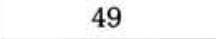 } & \multicolumn{2}{|c|}{105} & \multicolumn{2}{|c|}{221} \\
\hline
\end{tabular}

Uit Tabel 2 blyk dit dat Groep 1 die hoogste telling op sekuriteit as beroepsoriëntasie behaal het. Dit kan moontlik toegeskryf word aan hul gebrek aan blootstelling en ervaring in die beroepslewe. Sekuriteit as onderliggende behoefte behoort 'n primêre oorweging vir jong studente te wees, aangesien hulle in daardie stadium nog onseker is aangaande die korrektheid van hulle beroepskeuse en die ontplooiing van hul toekomstige beroepslewe. Die rekeningkunde kan ook beskryf word as 'n bekende tipe beroep wat 'n hoë waarskynlikheid van sekuriteit impliseer.

Die feit dat bestuursbedrewenheid as primêre oriëntasie vir Groepe 2 en 3 gerealiseer het, en as die tweede belangrikste oriëntasie van Groep 4, is op die oog af moeilik verklaarbaar. (Bestuursbedrewenheid is dan ook die oriëntasie wat vir die steekproef as geheel as die mees prominente oriëntasie gefigureer het). By Groep 2 kan dit moontlik toegeskryf word aan 'n persepsie van toekomstige finansiële bestuursposte wat by die respondente kon heers. In die geval van Groepe 3 en 4 kan die hoë belangrikheid van bestuursbedrewenheid moontlik aan drie faktore te wyte wees. In die eerste plek kan van die respondente moontlik reeds in toesighoudende posisies wees; tweedens kan hulle reeds bewus wees van 'n besliste strewe na 'n bestuursposisie en derdens kan daar onbevredigde magsbehoeftes en behoeftes aan beïnvloeding teenwoordig wees, wat op grond van die persepsie van die proefpersone deur die bekleding van bestuursposte bevredig kan word.

Dit dien ook gemeld te word dat bestuursbedrewenheid deur drie kernvermoëns en -vaardighede onderlê word, naamlik analitiese, interpersoonlike intergroep, en emosionele vaardighede (Schein, 1982b). Indien hierdie verskynsel in ag geneem word, kan daar in aansluiting met die drie faktore hierbo genoem 'n vierde afleiding gemaak word. Dit is naamlik dat die realisering van bestuursbedrewenheid as oriëntasie toegeskryf kan word aan óf die hoë premie wat in die rekeningkundige professie op analitiese vaardighede geplaas word, óf aan 'n selfwaargenome behoefte aan interpersoonlike intergroep en emosionele vaardighede. Indien laasgenoemde behoefte as ' $n$ faktor beskou word, kan dit gestel word dat daar inderwaarheid 'n behoefte aan bestuursontwikkeling by aspirant en gekwalifiseerde rekeningkundiges bestaan.

Indien daar wel ' $n$ behoefte aan onderlegging in bestuursvaardighede by rekeningkundiges sou bestaan, kan dit geïdentifiseer word as 'n wesenlike probleem in die professie in die lig 
van die bevindinge van Goosen (1984). Volgens dié navorser het 28 persent van Suid-Afrikaanse G.R.'s in 1984 bestuursposte beklee.

Verskeidenheid as dominante beroepsoriëntasie van Groep 4 kan verklaar word in die lig van die feit dat respondente in hierdie groep juis uit ouditeursfirmas na poste beweeg het wat 'n verskeidenheid take en uitdagings behels.

\section{STATISTIESE ONTLEDING}

Die metode van statistiese ontleding wat aangewend is vir die doel van die hipotesetoetsing is profielontleding, soos voorgestel deur Cronbach en Gleser (1953) en gebruik deur onder andere Joubert (1984). 'n Profiel word beskou as 'n stel metings van 'n individu of groep, waar elke stel in dieselfde eenheid van meting uitgedruk word. Dit blyk dat daar drie eienskappe van 'n profiel bestaan waarvolgens dit met ander profiele vergelyk kan word, naamlik vlak, verspreiding en vorm (Cronbach en Gleser, 1953; Kerlinger, 1973; Nunnally, 1978). Die vlak van 'n profiel word beskou as die rekenkundige gemiddelde van die skaaltellings van die proefgroep, die verspreiding dui op die mate waarin die onderskeie skaalwaardes afwyk van die gemiddelde (vlak) en die vorm toon die rangordes van tellings op elke skaal aan. Vir die doeleindes van die hipotesetoetsing van die huidige studie is die vorm en verspreiding van ' $n$ profiel geïdentifiseer as die wyses waarop die ooreenkomste en verskille tussen die proefgroepe bepaal kan word.

\section{Hipotesetoetsing}

\section{Hipotese 1}

Die metode waarvolgens bepaal kan word of professioneel-rekeningkundige persone oor verskillende beroepsoriëntasies tydens verskillende stadia van hul vroeë beroepsjare beskik, is die vergelyking van die vorme van die profiele van die proefgroepe. Die onderskeie vorme van die vier proefgroepe se profiele word in Figuur 1 aan die hand van profiele wat op grond van gemiddelde skaaltellings met mekaar vergelyk word, geillustreer:

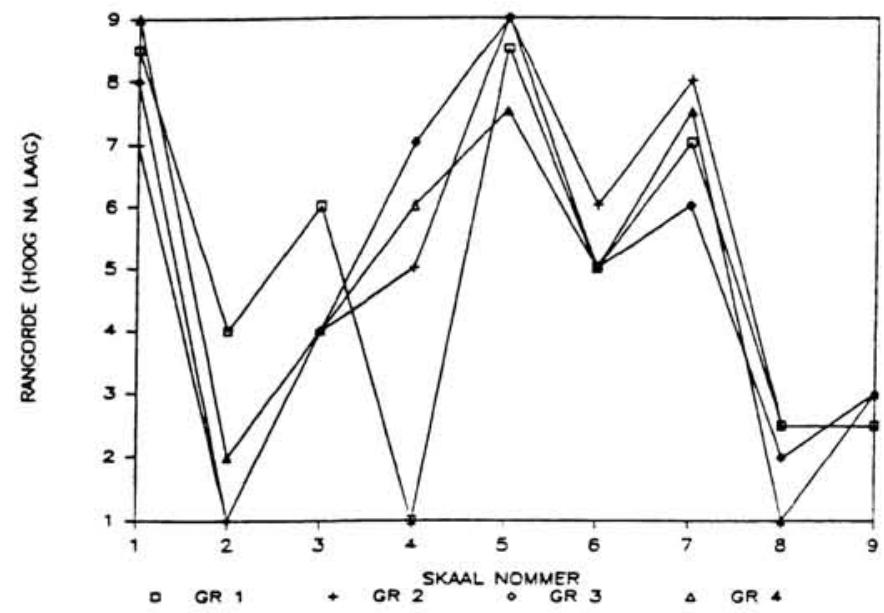

Figuur 1: Profiele op grond van 'n rangorde van gemiddelde skaaltellings

'n Skatting van die graad van ooreenkoms tussen die profielvorme kan uitgedruk word deur die koëffisiënt van ooreenstemming (W), soos voorgestel deur Kendall en beskryf in Guilford en Fruchter (1978) en Kerlinger (1973). So is bevind dat vir die vier groepe die grootte van $W=0,83$ is $(p<0,01$ ), en wat vorme betref die vier groepe se profiele dus in 'n hoë mate ooreenstem. Op grond hiervan is 'n skatting van die gemiddelde korrelasie van die vier groepe se rangordes verkry as 'n telling $\mathrm{r}=0,78$.

'n Fyner statistiese ontleding is die berekening van die Spearman se rangordekorrelasiekoëffisiënt $\left(\mathrm{r}_{\mathrm{p}}\right)$, met behulp waarvan aangetoon is dat die sterk ooreenstemming soos aangetoon deur die hoë koëffisiënt van ooreenstemming, toegeskryf kan word aan die hoë korrelasies tussen onderskeidelik Groepe 2 en 3, Groepe 2 en 4 en Groepe 3 en 4 . Genoemde korrelasies word weergegee in die onderstaande korrelasiematriks (Tabel 3).

TABEL 3

KORRELASIEMATRIKS TER ILLUSTRASIE VAN PROFIELVORMVERGELYKING

\begin{tabular}{llcccc}
\hline Groepe & $\mathbf{1}$ & $\mathbf{2}$ & $\mathbf{3}$ & $\mathbf{4}$ \\
\hline 1 & & 0,72 & 0,57 & 0,60 \\
2 & & & $0,91^{*}$ & $0,90^{*}$ \\
3 & & & $0,93^{*}$ \\
4 & & & & \\
& ${ }^{*} \mathrm{p} \leq 0,01$ & & &
\end{tabular}

Op grond van die bogenoemde resultate kan dit gestel word dat Hipotese 1 nie aanvaar kan word nie, en wel as gevolg van die hoë mate van ooreenstemming tussen die profielvorme van groepe 2, 3 en 4. Die afleiding wat dus hieruit verkry word, is dat uitgesonderd voltydse rekeningkunde-studente in hul eerste studiejaar, professioneel-rekeningkundige persone oor dieselfde beroepsoriëntasies beskik, ongeag die stadium van die vroeë beroepsjare waarin hulle hulself bevind. Dit blyk ook dat die stelling gemaak kan word dat beroepsoriëntasie eers na ten minste een jaar van werklike beroepsondervinding ontplooi, soos in die geval van Groepe 2, 3 en 4 en nie by persone betrokke by voltydse tersiêre opleiding nie.

\section{Hipotese 2}

Die metode op grond waarvan vasgestel is in watter mate die differensiasie van beroepsoriëntasies van professioneelrekeningkundige persone wat hulle in verskillende stadia van die vroeë beroepsjare bevind, verskil, is die ontleding van die relatiewe verspreiding van die verkreë beroepsoriëntasieprofiele. Die verspreiding van tellings binne elke groep kan dan op 'n verskeidenheid van wyses bereken en aangedui word, naamlik: variasiebreedte en die koëffisiënt van variasie (kyk Fallik en Brown, 1983), asook variansie.

Op grond van Figuur 2 wil dit voorkom asof beroepsoriëntasiedifferensiasie wel tydens verskillende stadia van die vroeë beroepsjare verskil. Die stelling word gemaak op grond van die feit dat dit blyk dat Groepe 3 en 4 'n groter verspreiding van skaaltellings (verkreë gemiddeldes) as Groepe 1 en 2 gerealiseer het. 

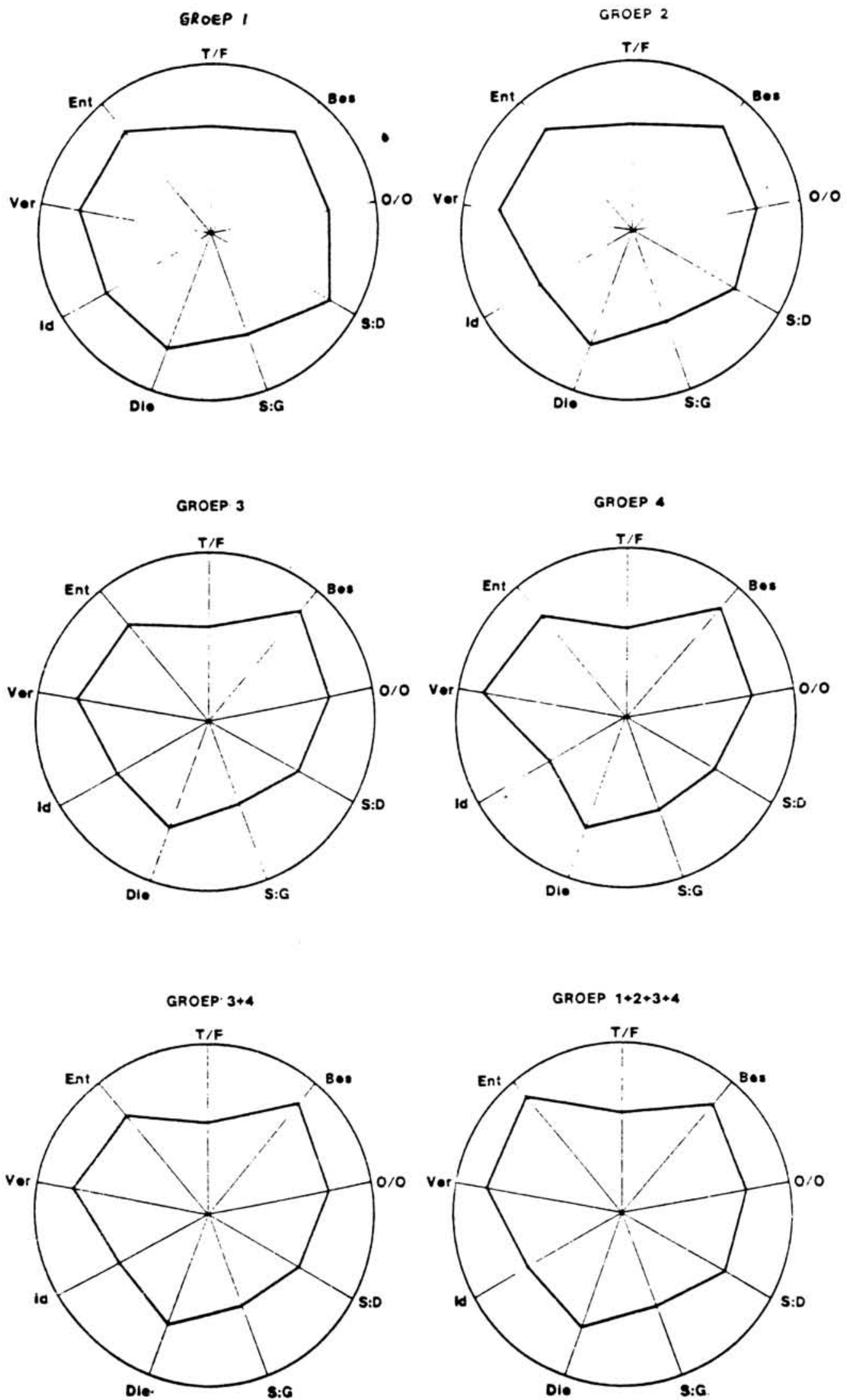

SLEUTE:-

S. S:Gt- Sekuriteit(Geografles)

1. TIF:- Tognies Funk sioneel

6. Die:- Dienslewering

2. Bes.:- Bestur

7. Id:- Orgenisasier Beroepsidentiteit

3. O/O:- Outonomier Onathankllkhoid

8. Ver:- Verskeidenheld

4. S:D:- Sokuritert(Dienetyd)

๑. Ent:- Entrepreneurskap/Kreatiwitelt

Figuur 2: 'n Grafiese voorstelling van die gerealiseerde beroepsoriëntasie 
Wanneer die profiele in Figuur 2 ten opsigte van die gemiddelde skaaltellings per groep in die lig hiervan beskou word, is die volgende opmerklik (kyk ook Tabel 4):

- Die variasiebreedte R (hoogste gemiddelde minus laagste gemiddelde) neem toe soos die groep onder beskouing aan meer beroepservaring blootgestel is. (Die variasiebreedte verdubbel vanaf Groep 1 na Groep 4).
- Die koëffisiënt van variasie V (standaardafwyking gedeel deur die gemiddelde telling vermenigvuldig met 100) neem op dieselfde wyse toe. (Die koëffisiënt van variasie verdubbel ook vanaf Groep 1 na Groep 4).

- Die variansies bereken oor die nege skaaltelling gemiddeldes toon dieselfde teoenamepatroon. (Die variansie van Groep 4 is bykans vier keer hoër as dié van Groep 1).

TABEL 4

VERSPREIDING VAN DIE GEMIDDELDE SKAALTELLINGS

\begin{tabular}{l|cccc}
\hline Skaal & Groep 1 & Groep 2 & Groep 3 & Groep 4 \\
\hline 1. Tegnies/Funksioneel & 3,79 & 3,72 & 3,30 & 3,09 \\
2. Bestuursbedrewenheid & 4,64 & 4,82 & 5,01 & 4,96 \\
3. Outonomie/Onafhanklikheid & 4,20 & 4,43 & 4,39 & 4,46 \\
4. Sekuriteit: Dienstydperk & 4,86 & 4,21 & 3,71 & 3,60 \\
5. Sekuriteit: Geografies & 3,79 & 3,37 & 3,21 & 3,50 \\
6. Dienslewering & 4,42 & 4,19 & 4,04 & 4,09 \\
7. Organisasie-/Beroepsidentiteit & 4,19 & 3,67 & 3,72 & 3,50 \\
8. Verskeidenheid & 4,70 & 4,72 & 4,67 & 5,05 \\
9. Entrepreneurskap/Kreatiwiteit & 4,70 & 4,72 & 4,44 & 4,63 \\
\hline Minimum & 3,79 & 3,37 & 3,21 & 3,09 \\
Maksimum & 4,86 & 4,82 & 5,01 & 5,05 \\
R & 1,07 & 1,45 & 1,80 & 1,96 \\
Variansie & 0,141 & 0,242 & 0,341 & 0,449 \\
V & 8,60 & 11,70 & 14,40 & 16,36 \\
\hline
\end{tabular}

Dit blyk gevolglik bloot op grond van die profiele in Figuur 2 dat die mate waarin beroepsoriëntasie gedifferensieer is, toeneem soos persone se beroepservaring toeneem. Dit kan ook uit Tabel 1 afgelei word dat beroepservaring en gevolglik differensiasie van beroepsoriëntasie vir die steekproef onder beskouing met ' $n$ toename in ouderdom ooreenstem.
Om die beduidenheid van bogenoemde tendens te bepaal, word die variansies van die gemiddelde skaaltelling per groep met behulp van 'n F-toets met mekaar vergelyk, soos aangetoon in Tabel 5.

TABEL 5

MATRIKS VAN F-WAARDES VAN VARIANSIES

\begin{tabular}{llccc}
\hline Groep & $\mathbf{1}$ & $\mathbf{2}$ & $\mathbf{3}$ & $\mathbf{4}$ \\
\hline 1 & & 1,72 & 2,42 & 3,19 \\
2 & & & 1,41 & 1,86 \\
3 & & & & 1,32 \\
\hline
\end{tabular}

(Vereiste F-waarde vir $\mathrm{p}<0,05$ is 3,44 )

Hoewel dit uit Tabel 5 afgelei kan word dat daar op die vyf persentvlak van betroubaarheid $(p<0,05)$ geen beduidende verskille tussen die variansies bestaan nie, is die verskil in variansie tussen die gemiddelde skaaltellings van Groepe 1 en 4 wel beduidend op die ses persent-vlak van betroubaarheid $(\mathrm{p}<0,06)$.

Dit kan dus gestel word dat Hipotese 2 op grond van die resultate in Tabel 5 nie aanvaar kan word nie. Wanneer daar egter na die resultate aangaande die variasiebreedte en die koëffisiënt van variasie gekyk word, kan die stelling gemaak word dat die hipotese nie sondermeer verwerp kan word nie. Voortspruitend hieruit kan daar beweer word dat daar wel aanduidings is dat die mate waarin die beroepsoriëntasie van professioneel-rekeningkundige persone gedifferensieer is, toeneem namate die persone hulself in meer gevorderde stadia van blootstelling aan beroepservaring bevind.

\section{GEVOLGTREKKINGS}

Betreffende die tipe beroepsoriëntasie van professioneelrekeningkundiges het dit aan die lig gekom dat bestuursbedrewenheid die mees prominente oriëntasie van die professioneelrekeningkundige groep respondente was. Sekuriteit het egter gefigureer as die gemete oriëntasie van die proefgroep wat oor geen beroepservaring beskik nie (eerstejaar rekeningkunde studente), en die verskeidenheid-oriëntasie is gerealiseer deur die groep met die meeste beroepservaring (Geoktrooieerde Rekenmeesters in die private en openbare sektor, uitgesonderd rekenmeester- en ouditeursfirmas). Daar is statisties bevind dat, uitgesonderd voltydse rekeningkunde-studente in hul eerste studiejaar, professioneel-rekeningkundige persone oor dieselfde beroepsoriëntasies beskik ongeag die beroepstadium waarin hulle hulself bevind. Aanduidings is ook verkry dat beroepsoriëntasiedifferensiasie van professioneel-rekeningkundiges toe- 
neem namate die persone hulself in meer gevorderde stadia van blootstelling aan beroepservaring bevind.

Dit kan aanbeveel word dat die beroepsankers van professioneel-rekeningkundige persone bepaal word deur die gestruktureerde onderhoud soos voorgeskryf in Schein (1982a) in samehang met die Career Orientation Inventory te gebruik. Verandering in beroepsankerprominensie en ontplooiing van ankers oor tyd behoort ook nagevors te word, veral dan ten opsigte van ander professionele beroepsgroepe.

Ten einde op 'n proaktiewe wyse moontlike intrapersoonlike konflik vir professioneel-rekeningkundige persone ten opsigte van die bekleding van bestuursposte te antisipeer, kan sterk oorweging geskenk word aan 'n verdere ondersoek rondom bestuursbedrewenheid as beroepsoriëntasie. Fynere analises van die implikasies van bestuursposisies vir professioneelrekeningkundiges kan oorweeg word, veral dan in terme van die persepsies wat ten opsigte van sulke bestuursposisies gekoester word; die gereedheid daarvoor in terme van nietaakgerigte dimensies; en die hantering van verskynsels waar beroepsoriëntasie op 'n nie-ooglopende wyse in konflik met die realiteit is.

\section{VERWYSINGS}

Aranya, N., Barak, A., \& Amernic, J. (1981). A test of Holland's theory in a population of accountants. Journal of Vocational Behavior, 19, 15-24.

Aranya N., \& Ferris, K. (1984). A reexamination of accountants' organizational-professional conflict. Accounting Review. 59(1), 1-15.

Aranya, N., Meir, E.I., \& Bar-Ilan, A. (1978). An empirical examination of the stereotype accountant based on Holland's theory. Journal of Occupational Psychology, 51, 139-145.

Aslanian, P.J., \& Duff, J.T. (1973). Why accounting teachers are so academic. Journal of Accountancy, 137, 47-53.

Bingham, W.C. (1983). The application of life stages to adult women's career behavior. International Journal of Advanced Counseling, 6, 281-288.

Bray, D.W., Campbell, J.J., \& Grant, D.L. (1979). Formative years in business. New York: Krieger.

Campbell, R.E., \& Heffernan, J.M. (1983). Adult vocational behavior. In W.B. Walsh \& S.H. Osipow (Eds.). Handbook of vocational psychology (Vol.1). Hillsdale, N.J.: Lawrence Erlbaum.

Carey, J.L. (1968). What is the professional practice of accounting? Accounting Review, 43(1), 1-9.

Cronbach, L.J., \& Gleser, G.C. (1953). Assessing similarity between profiles. Psychological Bulletin, 50(6), 456-473.

Dalton, G.W.. Thompson, P.H., \& Price, R.L. (1982). The four stages of professional careers: A new look at performance by professionals. In R. Katz (Ed.), Career issues in human resource management. Englewood Cliffs, N.J.: PrenticeHall.

De Coster, D.T., \& Rhode, J.G. (1972). Analysis of certified public accounting subgroup and accounting student personality traits using the California Psychological Inventory. Journal of Vocational Behavior, 155-162.

De Villiers, I.J. (1979). Die rekenmeestersprofessie in die 1980's. Johannesburg: RAU.

DeLong, T.J. (1982). Reexamining the career anchor model. Personnel, 59(3), 50-61.

Derr, C.B. (1980). More about career anchors. In C.B. Derr (Ed.), Work, family and the career: New frontiers in theory and research. New York: Praeger.

Fallik, F., \& Brown, B. (1983). Statistics for behavioral sciences. Homewood, III.: Dorsey.
Goetz, B.E. (1967). Professorial obsolescence. Accounting Review, 42, 53-61.

Goosen, A. (1984). Geoktrooieerde rekenmeester/ouditeur. In D. Ebersohn (Ed.), Beroepsinligting 1983. Pretoria: Raad vir Geesteswetenskaplike Navorsing.

Gould, S. (1979). Age, job complexity, satisfaction and performance. Journal of Vocational Behavior, 14, 209-223.

Graves, J.P. (1982). Successful management and organizational mugging. In R. Katz (Ed.), Career issues in human resource management. Englewood Cliffs, N.J.: PrenticeHall.

Gray, J.T. (1963). Needs and values in three occupations. Personnel and Guidance Journal, 42, 238-244.

Guilford, J.P., \& Fruchter, B. (1978). Fundamental statistics in psychology and education (6th ed.). Tokyo: McGraw-Hill Kogakusha.

Hall, D.T. (1976). Careers in organizations. Santa Monica. Calif.: Goodyear.

Hall, D.T. (1982). Potential for career growth. In M.A. Morgan (Ed.), Managing career development. Boston, Mass.: Kent.

Hall, D.T., \& Nougaim, K.E. (1968). An examination of Maslow's need hierarchy in an organizational setting. Organizational Behavior and Human Performance, 3, 12-35.

Healy, C.C. (1982). Career development: Counseling through the life stages. Boston, Mass.: Allyn \& Bacon.

Holland, J.L. (1973). Making vocational choices: A theory of careers. Englewood Cliffs, N.J.: Prentice-Hall.

Isaacson, L.E. (1985). Basics of career counseling. Newton, Mass.: Allyn \& Bacon.

Jacoby, P.F. (1980). An empirical descriptive study of selected personality characteristics of professional accountants based on Jungian typology. Ongepubliseerde proefskrif. George Washington University.

Joubert, J.P.R. (1984). Die semantiese differensiaal as opnametegniek vir die bepaling van maatskappybeleid. Ongepubliseerde magisterverhandeling. Johannesburg: RAU.

Kerlinger, F.M. (1973). Foundations of behavioral research (2nd ed.). New York: Holt, Rinehart \& Winston.

Levinson, D.J., Darrow, C.N., Klein, E.B., Levinson, M.H., \& McKee, B. (1978). The seasons of a man's life. New York: Ballantine.

Miller, D.C., \& Form, W.H. (1964). Industrial sociology: The sociology of work organizations (2nd ed.). New York: Harper $\&$ Row.

Nunnally, J.C. (1978). Psychometric theory (2nd ed.). New York: McGraw-Hill.

Rabinowitz, S., \& Hall, D.T. (1981. Changing correlates of job involvement in three career stages. Journal of Vocational behavior, 18, 138-144.

Schein, E.H. (1975). How "career anchors" hold executives to their career paths. Personnel, 52(3), 11-24.

Schein, E.H. (1978). Career dynamics: Matching individual and organizational needs. Reading, Mass.: AddisonWesley.

Schein, E.H. (1982a). Career anchors: An interview exercise in determining your career options and constraints. Cambridge, Mass.: M.I.T.

Schein, E.H. (1982b). Individuals and careers. Report for the Office of Naval Research - Organizational Effectiveness Group. Cambridge, Mass.: M.I.T.

Segal, S.J., \& Szabo, R. (1964). Identification in two vocations: Accountants and creative writers. Personnel and Guidance Journal, 42, 252-255.

Stumph, S.A., \& Rabinowitz, S. (1981). Career stage as a moderator of performance relationships with facets of job satisfaction and role perceptions. Journal of Vocational Behavior, 18, 202-218.

Super, D.E. (1968). Self concepts in vocational development. In D.G. Zytowski (Ed.), Vocational behavior: Readings in 
theory and research. New York: Holt, Rinehart \& Winston.

Tricker, R.I. (1967). The accountant in management. London: Batsford.

Van Maanen, J. (1977). Experiencing organization: Notes on the meaning of careers and socialization. In J. Van Maanen (Ed.), Organizational careers: Some new perspectives. New York: Wiley.

Webber, R.A. (1982). Career problems of young managers. In M.A. Morgan (Ed.). Managing career development. Boston, Mass.: Kent. 